\title{
Village Elders' Participation in Public Governance in Kenya: A Phenomenological Study
}

\author{
Jacqueline N. Mutua ${ }^{\circledR}$, Timothy Mwangi Kiruhi \\ School of Leadership and Governance, International Leadership University, Nairobi, Kenya \\ Email: jackiemutua3@gmail.com,tmkiruhi@gmail.com
}

How to cite this paper: Mutua, J. N., \& Kiruhi, T. M. (2021). Village Elders' Participation in Public Governance in Kenya: A Phenomenological Study. Open Journal of Leadership, 10, 110-128.

https://doi.org/10.4236/oj1.2021.102008

Received: April 27, 2021

Accepted: June 7, 2021

Published: June 10, 2021

Copyright (อ 2021 by author(s) and Scientific Research Publishing Inc. This work is licensed under the Creative Commons Attribution International License (CC BY 4.0).

http://creativecommons.org/licenses/by/4.0/

(c) (i) Open Access

\begin{abstract}
Village elders play an instrumental role in public governance in Kenya. Being at the grassroots level, they are the leaders closest to the people in terms of representing the interests of the government. Since they work as volunteer public servants, a focus on village elders in Kenya provides an interesting perspective to public governance. Globally, governments have embraced citizens' involvement in the decision-making process to increase the efficacy of regulation and improvement of the provision of public goods and services. Furthermore, volunteering is one of the ways that community members contribute to good governance, participate in government projects and reduce the public-government gap. Using a social capital theoretical framework, this phenomenological study sought to understand village elders' role in public governance and influence on community members' participation in government agenda. Thirty respondents including ten village elders, seven chiefs, and thirteen community members were purposively chosen to participate in the study. Collected data was analyzed using ATLAS.ti qualitative data analysis software. The study findings revealed that village elders made an attributable contribution to the provision of public goods and services as well as mobilization of community members for public participation.
\end{abstract}

\section{Keywords}

Volunteerism, Village Elders, Public Governance, Social Capital, Public Participation, Kenya

\section{Introduction}

Village elders in Kenya have long been involved in public governance at the grassroots level. Essentially, they are the Government of Kenya administrators at 
the village level (Gisore et al., 2012). Kenyan villages tend to be small in size, measuring around one and a half square kilometres and holding between 50 and 250 households (Ontita \& Chitere, 2015). In a public participatory process, the village elders are chosen from among community members depending on the length of time living in the community, knowledge of the community members, familiarity with the area, integrity, and educational level (Mbuba \& Mugambi, 2011). The chosen village elders command significant influence in the village and sit in most public committees within their territories (Andreassen \& Crawford, 2013). In colonial Kenya, the duties of village elders included maintaining law and order, collecting taxes, and regulating agriculture and people's movement (Mbuba \& Mugambi, 2011). The contemporary village elders are involved in solving disputes among conflicting members in the village they oversee, enforcing government regulations at the local levels, and security related issues (Haider, 2020; Nyamweru \& Chidongo, 2018), as well as enforcing health interventions such as immunization and vaccinations for children (Gisore et al., 2012). A study by Ontita and Chitere (2015) to establish factors that influence village elders' involvement in rural development activities in Kenya showed that village elders did not have any unique personal characteristics; these were however leaders closer to the community members. Owing to their proximity to citizens (village elders live in the same locality with the people they govern), the government can involve them in public governance.

Village elders oversee villages and work under the guidance of chiefs and assistant chiefs, and are the only cadre of public leaders in Kenya who work as volunteers (i.e. are non-salaried) (Gisore et al., 2012; Ontita \& Chitere, 2015; Nyamweru \& Chidongo, 2018). Volunteering is reported to contribute to good governance, promote participation in government projects as well as reducing the public-government gap (Soomro et al., 2016). Furthermore, volunteerism is considered a powerful means of engaging people in tackling development challenges by creating opportunities for participation, fighting exclusion, enhancing democratic engagement as well as responsible citizenry (Leigh et al., 2011). Moreover, volunteers tend to place a strong focus on human rights and inclusive participation benefitting small organizations in isolated areas (Lough \& Matthew, 2014). Relatedly, Suebvises (2018) noted that social capital influences the willingness and capacity of government officials and the public to work together to address common needs. In Kenya, public participation is a national value requiring the public to be involved in policymaking (Marine, 2015), and volunteering in community activities is perceived as part of public participation (Uraia, 2008).

Previous research on village elders focused on factors influencing their involvement (Ontita \& Chitere, 2015), how they were appointed into office (Ontita \& Chitere, 1991), specific roles such as crime control (Mbuba \& Mugambi, 2011), birth and death registration (Gisore et al., 2012), land allocation (Siakilo, 2014), and public health (Kamanda et al., 2013). There is however limited research that pays attention to village elders as volunteer leaders, their role in pub- 
lic governance as well as their contribution in supporting public participation for government projects. The current study investigates the participation of village elders in public governance and contribution to community participation in the government's agenda in Kenya. Specifically, the study was guided by the following objectives:

1) To analyze how village elders participate in governing at the village level.

2) To understand how community members perceive public participation at the community level.

3) To investigate how village elders influence community members to participate in the government agenda.

\section{Literature Review}

\subsection{Public Participation}

Onyimbi, Koeva and Flacke (2018) defined public participation as the process through which individuals who are likely to be affected by a decision are consulted in ensuring widely acceptable and sustainable decisions regarding a societal issue or problem. It includes engaging members of the public in decision-making when the issue at stake relates directly to them (The Republic of Kenya, 2016). Essentially, public participation is defined by such actions as voting, attending meetings, participating in public or private political discussions, signing petitions on the desired action, volunteering in community activities, or supporting a political party of choice (Uraia, 2008). Other forms of public participation include: informing the public on issues, options, and solutions; consulting with the public for feedback; involving the public in addressing their concerns; collaborating with the public to identify preferred solutions; and empowering the public by placing final decision-making authority in their hands (The Republic of Kenya, 2016). According to Mbithi, Ndambuki and Juma (2019), public participation aims at informing, engaging, consulting, collaborating, and empowering citizens through all stages of policymaking. Further, Foli and Van Belle (2015) posited that governments around the world have welcomed the idea of promoting interactions with citizens during the decision-making process, as a way of increasing the efficacy of regulation, improving the provision of public goods and services, and strengthening outcomes in areas such as health and education (Fung, 2015). The good governance approach emphasizes that the state collaborates with the citizens in decision-making to protect public and private interests (Katsamunska, 2016).

The core values of public participation include the belief that those affected by the decisions have a right to be involved in the decision-making process and the promise that their contribution will influence the decision. The effectiveness of public participation is dependent on accountability and transparency of leadership and funding (Marine, 2015). Njagi (2018) argued that training, social and economic factors influence public participation in legislative procedures. Further, Mbithi, Ndambuki and Juma (2019) posited that access to information on county budgets, legislation and projects, Members of County Assemby's (MCAs') 
responsiveness, governance performance, and corruption influence the level of meaningful engagement.

Enhancing public participation has benefits to the general population and the society at large. Public participation results in increased trust between public officials and the community, better-informed citizens with a sense of belonging, diverse views on issues, prioritized concerns, awareness of community concerns, and the ability of the public to effectively judge government responses (The Republic of Kenya, 2016). Furthermore, Opiyo (2017) posited that public participation influences the quality of projects and development as well as collaborative governance. It also strengthens the state by legitimizing governmental actions and democratic governance (The Republic of Kenya, 2018), as well as influencing budget implementation (Awire \& Nyakwara, 2019). According to Norglo et al. (2016), public participation improves policies, participants' capacity and social capital as well as providing legitimacy to public institutions' decisions. Moreover, it promotes sustainable decisions by taking into account the needs and interests of all the participants, provides information to participants on their need to participate, and communicate how their input affected the decision (The Republic of Kenya, 2016). According to Ronoh, Mulongo and Kurgat (2018) public participation is a form of empowerment and an important aspect of democratic governance.

Public participation however faces some challenges. Ronoh et al. (2018) highlighted some of the challenges to public participation as a negative attitude towards public participation; unwillingness of the public to participate; lack of political goodwill; incapacity to participate; political interference; demand for incentives; lack of time by the citizens; language used during public meetings; and short notice about public participation forums as well as inadequate time to reflect on development plans. Furthermore, Foli and Van Belle (2015) noted that reluctance and apathy from citizens towards interactions with government result from fear, the level of trust in the government, and privacy. Similarly, Fung (2015) argued that efforts to increase social justice through citizen participation face the greatest obstacles due to the absence of systematic leadership, the lack of popular consensus on the place of direct citizen participation, and the limited scope and powers of participatory innovations.

In Kenya, Marine (2015) noted that public participation is a national value, and is provided for in the Constitution of Kenya and instilled in the national values and principles of governance requiring national and county governments to engage the public in the processes of policymaking, monitoring, and implementation. Further, the constitution calls for meaningful public participation that has an impact on the policy-making process ushering in transparency, accountability, enhanced service delivery, equity, and inclusiveness (Mbithi, Ndambuki, \& Juma 2019). Notably, village elders play an important role in the empowerment of community members within villages (Akkas, 2014).

\subsection{Social Capital Theory}

Social capital is defined as the networks, norms, trust, and links of reciprocity 
that facilitate cooperation and coordination (Thompson, 2018; Wu et al., 2018; Inkpen \& Tsang, 2005; Ostrom \& Ahn, 2009; Putnam, Leonardi, \& Nanetti, 1993). Social capital according to Lee and Brudney (2012), increases the likelihood of volunteering by addressing the dilemmas of collective goods, providing a feeling of connection with beneficiaries of one's labor as well as increasing opportunities for future volunteering. Einolf et al. (2016) argued that informal volunteering is a form of social capital for it assists individuals to establish networks, norms, and trust that facilitate cooperation. Besides, volunteering can produce social capital (Martikke et al., 2019). Considering that in Kenya like in all other African countries voluntary activities are conceptualized in terms of mutual obligation, part of the responsibility of belonging to an extended family or community (Everatt et al., 2005), it influences the willingness and capacity of government officials and the public to work together to address common needs (Suebvises, 2018). As public participation focuses on togetherness of individuals for the common good, social capital becomes instrumental in this process.

Monteil, Simmons, and Hicks (2020) differentiated three types of social capital including bonding social capital existing among people who are similar in some key aspects, bridging social capital people in more heterogeneous groups while linking social capital involves associations with people who have access to power. Herrero (2018) noted that bonding social capital is formed in situations where individuals have between them intense relationships and goals while Campbell (2020) associated bonding social capital with marginalized communities. It is however noted that, while bonding social capital can lead to specific reciprocity and mobilization for solidarity, it has the potential to reinforce exclusion (Monteil et al., 2020). The village elders are similar to the community members they lead and they share bonding social capital. Additionally, public participation provides an opportunity for community members to link with people in power, suggesting that social capital is useful when it comes to public participation. Besides, King'e (1994) noted that the Seventh Adventist Church in Kenya was first established in South Nyanza and Gusii land and the churches' activities began there before spreading to other parts of the country. This possibly explains why most of the community members in the region are SDA adherents. Muthuri, Matten and Moon (2009) carried out a study to investigate the contribution of volunteering by employees in building social capital in three UK companies. The study showed that social capital is useful in explaining employee volunteering in the context of corporate social responsibility strategies and programmes. This makes social capital theory and in particular bonding and linking social capital relevant for this study.

\section{Methodology}

Using the qualitative phenomenological method, the study examined the involvement of village elders in public governance in Kenya. Qualitative research design was chosen for its orientation in analysing concrete cases in their tempo- 
ral and local particularity (Flick, 2018), and the potential of yielding a deeper understanding of a phenomenon (Patton, 2015). The research utilized phenomenology research methods to obtain data as understood from within and as experienced by the respondent (Patton, 2015). The approach focuses on the lived experiences of the people (Groenewald, 2004), as described by participants (Cresswell, 2015), and the context (Welman, Kruger, \& Mitchell, 2005), providing a rich textured description of the lived experience. As a method of data collection, phenomenology utilizes in-depth, open-ended interviewing and personal observation (Patton, 2015; Yeo et al., 2013) which is flexible enough to allow a holistic understanding of the interviewees' point of view or situation. The approach is appropriate for this study because volunteer leadership has not been studied much in Kenya.

Kenya has forty-seven (47) counties which are geographical units of devolved government. The counties are composed of sub-counties which are the decentralized units through which the county governments provide functions and services. Purposive sampling was employed (Cresswell, 2015) and Nyamira County was chosen because of the importance given to village elders in the area, and especially their usefulness in local dispute resolution (Ontita, 2007). Nyamira County is one of the two counties occupied by the Abagusii people (Nyamweya, Ogwora, \& Nyamwange, 2018). The county covers an area of $899.4 \mathrm{~km}^{2}$ with agriculture being the economic backbone and a projected population of 705,317 in 2018 of whom 52\% are female (The Republic of Kenya, 2018). The County has five sub-counties and Nyamira South Sub-county was selected due to the diversity of the inhabitants resulting from its urban and rural catchment, and the researcher's access. Furthermore, the Sub-county has five administrative wards and two wards were purposively chosen to include one in the urban setup and one in a rural setting. The two wards had two chiefs and nine assistant chiefs (seven in Nyamaiya and two in Township) each heading a sub-location. For this study, the assistant chiefs were referred to as chiefs so that all supervisors to village elders had one title. The two wards had a total of 138 (72 Nyamaiya, 66 Township) villages each headed by a village head. Thirty respondents participated in the study with ten village elders and seven chiefs providing information during interviews while thirteen select members of the community participated in focus group discussions. This is in line with Creswell's (1998) proposition of a sample of between 20 and 30 interviewees and precedence in qualitative research being between 10 and 30 respondents. The chiefs were requested to recommend outstanding village elders with the capacity to communicate fluently in English (most of the village elders had low levels of education and in the two wards only ten of them could communicate in English with ease). It was important for the study to be done in English to limit reliance on third parties for communication and to avoid misrepresentation of facts likely to happen during interpretation.

The village elders shared their experiences on their role, while the chiefs provided information on their engagement with village elders as their supervisors, and community members shared their experiences engaging with the village 
elders. The researcher explained to each of the participants, details of the study, and each one of them signed a consent form to participate in the study upon understanding the purpose of the study. All the interviews and FGDs were voice recorded. In addition, notes were taken to supplement the recorded responses which also formed part of the collected data for this study. Data was collected until saturation was achieved and encounters with new participants did not provide new information (Kuper et al., 2008).

Transcribed data was analysed using ATLAS.ti qualitative data analysis software for systematic organization, coding, and visualization. Data analysis was based on Braun and Clarke's (2013) guide on thematic analysis. The steps undertaken by the two authors were: familiarization with emerging data, development of initial codes from the data, collating and merging related codes. The codes were useful for the development of themes which were then aligned to the three study objectives. The trustworthiness of the study was enhanced by triangulation of methods (i.e. using interviews and FGD), as well as data analysis carried out by the two authors (Anney, 2014; Nowell et al., 2017).

Ethical clearance was obtained from the National Commission for Science, Technology, and Innovation (NACOSTI), the Kenyan body in charge of ethics in research. The permit number given for this study was

NACOSTI/P/19/75284/28956.

\section{Results and Discussion}

\subsection{Demographics}

The majority of the thirty respondents were male (90\%) while only three (10\%) were female including one chief and two community members. The fact that there was no female village elder who participated in the study was surprising and contrary to literature which had submitted that more females volunteered (Cemalcilar, 2009). However, the finding was in line with Einolf's (2011) argument that men possess some advantages in social capital than women due to their wider secular societal networks and more local trust which are considered critical in the selection into leadership positions. In addition, men have been shown to be more likely to volunteer for political organizations, unlike women volunteers who are more attracted to caregiving organizations (Greif, Adamczyk, \& Felson, 2011). Similar to other patriarchal societies, leadership, and decisionmaking in the community is dominated by men (Nyamweya, Ogwora, \& Nyamwange, 2018). Moreover, Nzomo (2011) posited that entrenched patriarchal social-cultural values, contributed to the slow progress of the involvement of women in formal political leadership positions. Besides, at the national level, women are seemingly side-lined and inadequately represented in the country's decisionmaking organs and governance structures (Kivoi, 2014).

In terms of age, fourteen respondents were aged between twenty-five and forty-five years. Thirteen were between forty-six and sixty-five years while three were above sixty-five years old. Out of the ten village elders, one (10\%) was aged 
twenty-seven years fitting the official Kenyan definition of youth (18 to 35 years). Six of them (60\%) were above 50 years. The rest were between thirty-five and forty-five years (30\%). The age factor was especially emphasized by the chiefs and there seemed to be an unspoken expectation that the village elders should be elderly. The seemingly higher age of the volunteer leaders was in line with Wymer's (1998) assertion that volunteers were more probable to be older and Reed and Selbee's (2001) argument that volunteering peaks in the late 40s and 50s declining thereafter. Besides Hackl, Halla, and Pruckner (2007) posited that when people get older, they provide volunteer labor to take care of their mental and physical health as well as for enjoyment.

The thirty respondents reported professing the Christian faith (ten catholic and twenty Protestants). Of the ten village elders, three were catholic and seven Protestants. Out of the seven Protestants, five professed the Seventh Day Adventist faith which is the dominant religion in the county, and the findings may be influenced by the SDA beliefs and values. Spiritual persuasion was reported to have been important with all the village elders reporting that they prayed for guidance and depended on religious books in ensuring justice and fairness. That all the respondents reported professing the Christian faith (three catholic and seven protestants), agrees with Greif, Adamczyk and Felson (2011) that religious people were more likely to take part in volunteering and Reed and Selbee's (2002) assertion that actively practicing Protestants were more likely to volunteer, for the protestant church encourages the pursuit of social responsibility (Lam, 2002). Furthermore, literature showed a positive relationship between individual religiosity and volunteer motivation (Haers \& Essen, 2015; Bennett, 2015), and underpinning values of caring for other people in many cultures (Rochester et al., 2016).

All thirty respondents (100\%) were currently married and living with their families. The chiefs and community members seemed to be keen that for anyone to play the role of the village elder effectively, they needed to be married and managing their families well. There was an underlying expectation that this is the only way they would be able to understand and assist in resolving community members' issues. This supported Reed and Selbee's (2001) position that married individuals were more likely to volunteer than the single counterparts. It also concurred with Yao's (2015) argument that marital status was one of the critical attributes of volunteering just like age, religion, the number of children, and social position impact. Marriage and the ability to manage family well were seen as providing an experience that was required to address the key issues in the community which mainly revolved around family disputes.

Out of the thirty respondents, seven had attained primary level education, eleven high school level, four tertiary, seven diploma and one bachelor's degree level. Only ten out of one hundred and thirty-eight village elders (72 in Nyamaiya, 66 in Township) were reported to have the ability to communicate fluently in English. The fact that village elders led at the lowest level of the community shows that education may not have been a major requirement. 


\subsection{How Village Elders Participate in Public Governance}

When a position fell vacant either due to the death of the occupant or inability to continue with the role, community members were allowed to nominate one of their own to fill the leadership position. The nominated persons were then subjected to a vote during a public gathering locally known as "baraza" and the one with the highest votes was confirmed as the village elder. The village elders were respected in the community, recognized for the role they played, and got opportunity to interact with other cadres of leaders including members of the county assembly, religious leaders, members of parliament, and the governor with whom they worked for the betterment of the community members. The term "clan elders" was interchangeably used for "village elders" meaning that the position is still influenced by the patrilineal and patriarchal nature of the Abagusii society. The elders meet when there is a need and when they are called upon by the chief. There was no evidence that documentation of the meetings was done.

Asked what role the village elders play, all the respondents noted that the position of village elders is a vital tool for the social development and security of the community. According to the coding frequency by respondents, the village elders contributed more than $45 \%$ while the chiefs provided $26 \%$ and community members $28 \%$. The main themes included security, conflict resolution, education, and health. The village elders focused on roles that could be attributed to their legacy while the chiefs' perception of the contribution of the position was related to the role that village elders played in supporting them in the community. The village elders highlighted the elimination of local brew, crime, and reduction of school dropouts in the village. Other contributions involved resolving family differences, boundary disputes, and different cases in the community. They also mobilized the community to carry out projects for financial independence. Generally, they made contributions to security as reported by a 41-year-old male village elder:

There was much insecurity. I was a victim one time when some young men came and stole my goats but now I can say that we have security within our village and along our roads. People can move freely without being attacked, or their property.

It was also evident that village elders made contributions to education as part of their public governance, as testified by a 45 -year-old male village elder:

In my village, I don't want any dropouts. When I come across such a situation, I inform the assistant chief immediately. Then we go and talk to the parent, pick the child, and contact the head teacher or principal ...

Healthcare is one sensitive area in Kenya, more so at the grassroots levels. Village elders reported that they also participated in making contributions to health care. For example, a 59-year-old male village elder revealed:

I am proud that in my village, every home has a toilet of which was not there formerly.

Other social issues the village elders were involved in include supporting 
socio-economic programmes, as well as dealing with social challenges such as preparation and consumption of illegal brew, which is quite pervasive in many villages in Kenya.

We were able to eliminate this issue of the local brew being brewed in our village, completely.

( $A$ 41-year-old male village elder)

When people come together, when the government has money or loans, we tell them to come together, to contribute and come to ask for loans.

( $A$ 62-year-old male village elder)

Although the responses by the chiefs were similar to those provided by the village elders, they focused on the roles village elders played in assisting them to manage the villages. Notably, village elders being closer to community members are likely to have more fruitful and engaging relationship than the chiefs' relationship with community members. The chiefs noted that the village elders' contribution was related to their proximity to the community members and presence in the village, therefore, being able to pick information from the community and sharing with the chiefs as well as reporting on visitors coming in and out of the village. The village elders also influenced community members to take their children to school and report those who refused to do so to a higher authority for action.

The chiefs also reported that village elders encouraged community members to abide by public health guidelines, as well as, report when there was an outbreak of disease. Whenever an issue of concern arose, community members raise such through the village elders. Improved security as a result of village elders' continued efforts to emphasize peace and settling issues as soon as they occur in the community without letting them escalate to the chief, as reported by a chief who had held the position for three and half years:

These people walk around the community so, they give you information, they assist a lot, health issues, education, some small projects, even people who come to hide here, a village elder can assist you because someone can come and live in someone's place and you do not know but the village head sees and tells you there are some people somewhere.

Furthermore, village elders ensure there is peace, harmony, law, and order in the village. They support dispute resolution by being able to handle and complete simple cases (domestic, border) at the village level. A male chief who has held the position for ten years reported that simple cases were handled at the village elders' level:

... some of them have assisted so much in domestic issues, they know how to handle them, they do not come to us, otherwise we could have been having a very big queue of cases. Most of them end there, family disputes, land disputes...

From the FGD with community members, it was apparent that village elders worked towards peace in their areas of jurisdiction, and helped the chiefs and assistant chiefs in public governance and leadership at the village level: 
You see these people (village elders), they are peacemaking people and they assist the assistant chief and chief come up with what they want to be done.

The first objective sought to analyse how village elders participate in public governance at the village level. Similar to observations and findings by Haider (2020), Gisore et al. (2012), Ontita and Chitere (2015) as well as Nyamweru and Chidongo (2018), findings in this study show that villages elders contributed to public participation and governance by handling disputes in their communities, dealing with arising security matters, and promoting socio-economic programs such as education and financial projects by community members. Specifically, villager elders promoted health initiatives as revealed by Gisore et al. (2012). Further, dealing with the illegal brew that is commonplace in villages in Kenya (named chang' aa and busaa) was one of the tasks village elders carried out, and similarly observed by Nyamweru and Chidongo (2018) in their study. As Haider (2020) noted, village elders were also instrumental in dealing with security-related issues that affected their specific villages. Literature has also shown that one of the village elders' major roles was to defend villagers in the face of unfair external demands (Ontita \& Chitere, 2015), and which was evident in this study.

Similarly, the contributions highlighted by the respondent are similar to those in reviewed literature which showed that volunteerism contributes to good governance (Lough \& Matthew, 2014), a country's social, economic, and political development (The Republic of Kenya, 2016), the productivity of the public institutions (Soomro et al., 2016), social connections between different sectors and active civic engagement ( $\mathrm{Wu}$ et al., 2018). The village elders were proud of the difference they had made in their community as they served in the position with a substantial contribution to security, education, health, social and economic development.

\subsection{Community Members' Perceptions of Public Participation}

The chiefs, village elders, and community members observed that public participation is important. According to the coding frequency by respondents, the village elders contributed $32 \%$, chiefs $22 \%$, and community members $46 \%$. The emerging themes included ownership, benefits, monitoring projects, and misuse. Public participation provides community members an opportunity to know what the government is doing, the chance to know that their ideas are incorporated into government projects, and community members get to appreciate the benefits of the projects. A male chief who had held the position for three and a half years, observed:

They [community] become aware of what is being done by the government, how it is done, and what the benefits are. The people need to be involved and take initiative by joining or following to benefit.

Similarly, a male chief who had held the position for 20 years noted that community participating in public governance was crucial for members' approval of projects being done:

It is important they [community] be incorporated. So that they can be seen 
whether they like that project or not. Because you might come up with a project and they don't like it. So what is the use for it?

A female chief who had held the position for close to four years echoed a related observation:

Yes because they are coming for whatever services are being offered for the benefit of the community. So once they are involved, they feel they own that and their views are heard. So they are part of whatever is being implemented, they take it positively

Even then, all was not rosy. A male chief who had held the position for seven years noted that there was laxity among community members when they did not see immediate implementation.

Because they [ what the community members requested] are never initiated on the ground, now it makes the community feel that that's a waste of time, even if you go and you participate in anything there is nothing which can be done. It is just a waste of time [for them] .... And there is this notion which has come up to people that public participation is helping maybe the government or the government officers to pass a budget which will benefit them [public officers].

On their part, the community members considered public participation as a way of monitoring government activities as reported below from a focus group discussion in the rural ward:

So what we do when it is public participation, we take our own problems to the participation of the panel so that we can give our grievances as well as identify here is where we want this, here is where you get this. You gave money and something was not done. In other words, we are monitoring government activities.

Further, public participation to community members ensured that resources were distributed equally and that no clan was discriminated against, as seen in this response from the FGD in the rural setting:

Every clan has its own problems and you know this participation has brought clannism to an end because it has become everybody's project, if you have this project, you can't take two, you take one, the other one takes one. So everybody is served by the same government, same budget, but the same people benefit all of them.

Findings from the second objective mirrored those of reviewed literature which had revealed that public participation increases trust between public officials and the community and makes better-informed citizens with a sense of belonging (The Republic of Kenya, 2016); and empowers (Ronoh et al., 2018). Furthermore, Marine (2015) posited that the effectiveness of public participation depended on accountability and transparency of leadership and funding. Evidently, the community members' mistrust and suspicion were seen when they expressed doubt concerning projects that either had not been implemented or delayed.

Khalid and Thompson (2019) as well as Nunkoo, Ramkissoon and Gursoy 
(2012) as well observed that the way public institutions handle resources entrusted unto them affects the community members' trust for them, which was similar to findings in this study. Relatedly, the aspect of "monitoring" kept coming up in relation to public participation at the village level. Owing to history and presence of numerous corruption cases in the country (Hope, 2019; Transparency International Kenya, 2019), as well as tribalism and ethnicity (Taaliu, 2017), community members seemingly felt obliged to take the "monitoring" role in relation to resource distribution and allocation at the village level.

Also, while the community felt a sense of ownership when they were involved in governing at the village level, a sense of despair seemed apparent when their views were either not listened to, or when their ideas were not taken into consideration. Studies have shown that effective development at the grassroots levels takes place when members are involved, rather than when it is decided for them (Morris, 2003; Thomas \& Mefalopulos, 2009). This finding is also in line with the tenets of social capital where mutual cooperation is expected for communal projects at village levels (Everatt et al., 2005).

\subsection{How Village Elders Influence Community Members to Participate in Government Agenda}

The chiefs noted that village elders can influence community members either positively or negatively. They do this by creating awareness, convincing them, and being good examples. According to the coding frequency by respondents the village elders contributed $11 \%$ and chiefs $89 \%$. The generated themes included proximity to community members, inspiring community members and perception of village elders by community members. The chiefs noted that the relationship between village elders and community members was close. In return, the community members could confide in them; they were in touch with what is happening at the village level; they were of the same family as other community members in the village and that is why they are chosen. In this regard, a male chief who had held the position for close to four years observed:

Whenever a need arises, they are the people we send to the ground, so they disseminate the information, right information about public participation

Similarly, a male chief who had held the position for seven years highlighted:

$A$ village head is a role model in that village and being a role model, people trust that whatever the village head tells them must be true, and is real, and is good.

On village elders' influence, a male chief who had held the position for around a year noted:

You know, they can influence positively or negatively. So the village elders, most of them support government projects by telling the community the goodness of a project, they can sensitize the community, they can tell them the goodness of a project.

The village elders' close relationship with the community members and the ability to respond quickly to matters made the community members have confi- 
dence in their leadership. Furthermore, they were respected, appreciated and community members trusted in what they did, thereby, positively responding to their leadership like attending meetings when invited and participating in projects. From the FGD with community members, this observation was made:

We participate when we get the chance because there is some time in public participation that select people and then a few people get a chance to be there.

The village elders similarly noted that their proximity to community members enabled them to have a better understanding of their worldview and devise effective communication styles.

The close relationship between the village elders and community members was in line with Salacuse's (2005) position that volunteer leaders develop relationships that encourage followers to grant permission to lead. Furthermore, Bowers (2012) posited that volunteer leaders appeared to work diligently at building trust with followers and ensuring their interests, getting personally involved in their lives, and providing social support.

It was apparent that village elders influenced their community members by providing them with the right information on socio-economic developments as observed by Gisore et al. (2012) as well as Nyamweru and Chidongo (2018) in their studies. Further, the role of village elders as role models was similarly rubber-stamped, with observations that although their positive modelling was bound to encourage citizens to be loyal to government policies and practices, they could also sway and mislead community members if they took up negative behaviours or influence. Generally, leadership is often perceived as influence (Avolio, Walumbwa, \& Weber, 2009), and this was evident in the village elders at the local community level.

\section{Conclusion and Implication}

This study has demonstrated that village elders are a vital tool for the social development and security of the community in Kenya. Through their volunteer work, and in line with Social Capital Theory, village elders teamed up with their supervisors (chiefs and assistant chiefs) and the community members in enhancing public participation at the village level. For example, they contributed to the elimination of local brew, crime, and reduction of school dropouts in the village. They were also involved in resolving family differences, boundary disputes, and other cases in the community, as well as, mobilizing the community to carry out projects that give them financial independence. As a result of their close connection with community members, they influenced community members to participate in public fora discussing government projects by creating awareness, convincing them, and being good examples.

An implication from this study regards giving more attention to village eldership, to improve public governance in Kenya. Not much attention has been given hitherto to this local yet important office. With the devolved system of governance currently in place, focussing more attention on village eldership is 
instrumental in the realization of Sustainable Development goals, more so those on education and health, two areas that Kenya faces a great challenge (Ministry of Devolution and Planning, 2017). More resources could for example be provided to make the position more effective.

The study was limited considering that the findings in this study reflect the situation in Nyamira County in Kenya, and they should not necessarily be generalized. This is typical of qualitative studies whose aim is to provide unique contextual and subjective experiences (Yilmaz, 2013). Further research is recommended to include both quantitative and qualitative approaches using a bigger sample that is more balanced in terms of gender and age and therefore can be generalized.

\section{Conflicts of Interest}

The authors declare no conflicts of interest regarding the publication of this paper.

\section{References}

Akkas, Z. (2014). Women's Participation in Communal Activities in Rural Bangladesh. Local Government Studies, 40, 495-517. https://doi.org/10.1080/03003930.2013.795889

Andreassen, B. A., \& Crawford, G. (2013). Kenya: Civic Action from Confrontation to Collaboration? In B. A. Andreassen, \& T. Barasa (Eds.), Human Rights, Power and Civic Action (pp. 65-97). London: Routledge. https://doi.org/10.4324/9780203525821

Anney, V. N. (2014). Ensuring the Quality of the Findings of Qualitative Research: Looking at Trustworthiness Criteria. Journal of Emerging Trends in Educational Research and Policy Studies (JETERAPS), 5, 272-281.

Avolio, B. J., Walumbwa, F. O., \& Weber, T. J. (2009). Leadership: Current Theories, Research, and Future Directions. Annual Review of Psychology, 60, 421-449. https://doi.org/10.1146/annurev.psych.60.110707.163621

Awire, J. W., \& Nyakwara, S. (2019). Analysis of Public Participation on Budget Implementation in Kisii County Government, Kenya. European Journal of Business and Management, 11, 68-78.

Bennett, M. R. (2015). Religiosity and Formal Volunteering in Global Perspective. In Religion and Volunteering (pp. 77-96). Cham: Springer.

https://doi.org/10.1007/978-3-319-04585-6 5

Bowers, K. M. (2012). An Exploration of the Leadership Behavior of Volunteer Leaders. Indiana Wesleyan University. https://www.proquest.com/openview/88611c508e255b4635bfd0e9b0dc905f/1?pq-origsi $\underline{\text { te }=\text { gscholar } \& \mathrm{cbl}=18750 \& \text { diss }=\mathrm{y}}$

Braun, V., \& Clarke, V. (2013). Successful Qualitative Research: A Practical Guide for Beginners. London: SAGE.

Campbell, C. (2020). Social Capital, Social Movements and Global Public Health: Fighting for Health-Enabling Contexts in Marginalised Settings. Social Science \& Medicine, 257, Article ID: 112153. https://doi.org/10.1016/j.socscimed.2019.02.004

Cemalcilar, Z. (2009). Understanding Individual Characteristics of Adolescents Who Volunteer. Personality and Individual Differences, 46, 432-436.

https://doi.org/10.1016/j.paid.2008.11.009

Cresswell, J. W. (2015). A Concise Introduction to Mixed Methods Research. London: 
SAGE.

Creswell, J. W. (1998). Qualitative Inquiry and Research Design: Choosing among Five Traditions. Thousand Oaks, CA: Sage Publications.

Einolf, C. J. (2011). Gender Differences in the Correlates of Volunteering and Charitable Giving. Nonprofit and Voluntary Sector Quarterly, 40, 1092-1112. https://doi.org/10.1177/0899764010385949

Einolf, C. J., Prouteau, L., Nezhina, T., \& Ibrayeva, A. R. (2016). Informal, Unorganized Volunteering. In D. H. Smith, R. A. Stebbins, \& J. Grotz (Eds.), The Palgrave Handbook of Volunteering, Civic Participation, and Nonprofit Associations (pp. 223-241). London: Palgrave Macmillan. https://doi.org/10.1007/978-1-137-26317-9 10

Everatt, D., Habib, A., Maharaj, B., \& Nyar, A. (2005). Patterns of Giving in South Africa. Voluntas: International Journal of Voluntary and Nonprofit Organizations, 16, 275291. https://doi.org/10.1007/s11266-005-7725-Z

Flick, U. (2018). An Introduction to Qualitative Research (6th ed.). London: Sage.

Foli, M., \& Van Belle, J. P. (2015). Using Mobile Phones for Public Participation with Local Government in Cape Town. 2015 IST-Africa Conference IEEE, Lilongwe, 6-8 May 2015, 1-10. https://doi.org/10.1109/ISTAFRICA.2015.7190526

Fung, A. (2015). Putting the Public Back into Governance: The Challenges of Citizen Participation and Its Future. Public Administration Review, 75, 513-522.

https://doi.org/10.1111/puar.12361

Gisore, P. et al. (2012). Community Based Weighing of Newborns and Use of Mobile Phones by Village Elders in Rural Settings in Kenya: A Decentralised Approach to Health Care Provision. BMC Pregnancy and Childbirth, 12, 15.

https://doi.org/10.1186/1471-2393-12-15

Greif, M. J., Adamczyk, A., \& Felson, J. (2011). Religion and Volunteering in Four SubSaharan African Countries. Interdisciplinary Journal of Research on Religion, 7, 11.

Groenewald, T. (2004). A Phenomenological Research Design Illustrated. International Journal of Qualitative Methods, 3, 42-55. https://doi.org/10.1177/160940690400300104

Hackl, F., Halla, M., \& Pruckner, G. J. (2007). Volunteering and Income-The Fallacy of the Good Samaritan? Kyklos, 60, 77-104. https://doi.org/10.1111/j.1467-6435.2007.00360.x

Haers, J., \& Von Essen, J. (2015). Christian Calling and Volunteering. In Religion and Volunteering (pp. 23-40). Cham: Springer. https://doi.org/10.1007/978-3-319-04585-6_ 2

Haider, H. (2020). Conflict Analysis of North Eastern Kenya: K4D Emerging Issues Report 36. Brighton: Institute of Development Studies.

Herrero, I. (2018). How Familial Is Family Social Capital? Analyzing Bonding Social Capital in Family and Nonfamily Firms. Family Business Review, 31, 441-459. https://doi.org/10.1177/0894486518784475

Hope, K. R. (2019). The Police Corruption “Crime Problem” in Kenya. Security Journal, 32, 85-101. https://doi.org/10.1057/s41284-018-0149-y

Inkpen, A. C., \& Tsang, E. W. (2005). Social Capital, Networks, and Knowledge Transfer. Academy of Management Review, 30, 146-165.

https://doi.org/10.5465/amr.2005.15281445

Kamanda, A. et al. (2013). Harnessing the Power of the Grassroots to Conduct Public Health Research in Sub-Saharan Africa: A Case Study from Western Kenya in the Adaptation of Community-Based Participatory Research (CBPR) Approaches. BMC Public Health, 13, 91. https://doi.org/10.1186/1471-2458-13-91 
Katsamunska, P. (2016). The Concept of Governance and Public Governance Theories. Economic Alternatives, 2, 133-141.

Khalid, H., \& Thompson, T. P. (2019). Conflict Prevention in Kenya: Combating Corruption through Nonviolent Action. Washington DC: United States Institute of Peace.

King'e, K. P. (1994). Establishment of the Seventh Day Adventist Church in Central Kenya. Doctoral Dissertation.

Kivoi, D. L. (2014). Factors Impeding Political Participation and Representation of Women in Kenya. Humanities and Social Sciences, 2, 173-181.

https://doi.org/10.11648/j.hss.20140206.15

Kuper, A., Lingard, L., \& Levinson, W. (2008). Critically Appraising Qualitative Research. BMJ, 337, a1035. https://doi.org/10.1136/bmj.a1035

Lam, P. Y. (2002). As the Flocks Gather: How Religion Affects Voluntary Association Participation. Journal for the Scientific Study of Religion, 41, 405-422. https://doi.org/10.1111/1468-5906.00127

Lee, Y. J., \& Brudney, J. L. (2012). Participation in Formal and Informal Volunteering: Implications for Volunteer Recruitment. Nonprofit Management and Leadership, 23, 159-180. https://doi.org/10.1002/nml.21060

Leigh, R. et al. (2011). State of the World's Volunteerism Report, 2011: Universal Values for Global Well-Being. United Nations Volunteers. Bonn: United Nations Volunteers.

Lough, B. J., \& Matthew, L. E. (2014). International Volunteering and Governance. Bonn: UN Volunteers.

Marine, J. (2015). A Preliminary Comparative Study of Public Participation Acts in Kenya: A Case Study of Meru, Elgeyo/Marakwet \& Machakos Counties. Proceedings of the 38th AFSAAP Conference: 21st Century Tensions and Transformation in Africa, Melbourne, 28-30 October 2015, 1-17.

Martikke, S. et al. (2019). Building Bridges into the Community: Social Capital in a Volunteering Project for Care Leavers. Children \& Society, 33, 111-125. https://doi.org/10.1111/chso.12300

Mbithi, A., Ndambuki, D., \& Juma, F. O. (2019). Determinants of Public Participation in Kenya County Governments. Journal of Asian and African Studies, 54, 52-69. https://doi.org/10.1177/0021909618794028

Mbuba, J. M., \& Mugambi, F. N. (2011). Approaches to Crime Control and Order Maintenance in Transitional Societies: The Role of Village Headmen, Chiefs, Sub-Chiefs and Administration Police in Rural Kenya. African Journal of Criminology and Justice Studies: AJCJS, 4, 1.

Ministry of Devolution and Planning (2017). Implementation of the Agenda 2030 for Sustainable Development in Kenya Report. Nairobi, Kenya: Ministry of Devolution and Planning.

Monteil, C., Simmons, P., \& Hicks, A. (2020). Post-Disaster Recovery and Sociocultural Change: Rethinking Social Capital Development for the New Social Fabric. International Journal of Disaster Risk Reduction, 42, Article ID: 101356. https://doi.org/10.1016/j.ijdrr.2019.101356

Morris, N. (2003). A Comparative Analysis of the Diffusion and Participatory Models in Development Communication. Communication Theory, 13, 225-248. https://doi.org/10.1093/ct/13.2.225

Muthuri, J. N., Matten, D., \& Moon, J. (2009). Employee Volunteering and Social Capital: Contributions to Corporate Social Responsibility. British Journal of Management, 20, 75-89. https://doi.org/10.1111/j.1467-8551.2007.00551.x 
Njagi, M. E. (2018). Factors Affecting Public Participation in Legislative Procedures in County Governments: A Case of Embu County Assembly. Doctoral Dissertation, MUA, Nairobi: Management University of Africa.

Norglo, B. E. K., Goris, M., Lie, R., \& Ong'ayo, A. O. (2016). The African Diaspora's Public Participation in Policy-Making Concerning Africa. Diaspora Studies, 9, 83-99. https://doi.org/10.1080/09739572.2016.1183889

Nowell, L. S., Norris, J. M., White, D. E., \& Moules, N. J. (2017). Thematic Analysis: Striving to Meet the Trustworthiness Criteria. International Journal of Qualitative Methods, 16, 1-13. https://doi.org/10.1177/1609406917733847

Nunkoo, R., Ramkissoon, H., \& Gursoy, D. (2012). Public Trust in Tourism Institutions. Annals of Tourism Research, 39, 1538-1564.

https://doi.org/10.1016/j.annals.2012.04.004

Nyamweru, C., \& Chidongo, T. M. (2018). Elders in Modern Kenya: "Dying Institutions" or "Reinventing Themselves"? African Studies, 77, 240-256. https://doi.org/10.1080/00020184.2018.1452857

Nyamweya, F., Ogwora, E., \& Nyamwange, C. (2018). The Impact of Cultural Perceptions on Women's Participation in Leadership among the Abagusii, a Case of Kitutu Masaba Constituency, Nyamira County, Kenya. International Journal of Social Sciences and Information Technology, 4, 52-71.

Nzomo, M. (2011). Women in Political Leadership in Kenya: Access, Agenda Setting \& Accountability. Nairobi: Institute of Diplomacy \& International Studies, University of Nairobi.

Ontita, E. (2007). Creativity in Everyday Practice: Resources and Livelihoods in Nyamira, Kenya. Wageningen: Wageningen Universiteit.

Ontita, E. G., \& Chitere, O. (1991). The Role of Village Headmen in Rural Development. Nairobi: University of Nairobi.

Ontita, E. G., \& Chitere, O. (2015). Village Communities in Kenya: A Case Study of Kabras. In O. P. Chitere, \& R. Mutiso (Eds.), Working with Rural Communities Participatory Action Research in Kenya (pp. 101-114). Nairobi: University of Nairobi Press.

Onyimbi, J. R., Koeva, M., \& Flacke, J. (2018). Public Participation Using 3D Web-Based City Models: Opportunities for e-Participation in Kisumu, Kenya. ISPRS International Journal of Geo-Information, 7, 454. https://doi.org/10.3390/ijgi7120454

Opiyo, S. A. (2017). Role of Public Participation on Performance of Devolved Governance Systems in Kenya. Doctoral Dissertation, Nairobi: Jomo Kenyatta University of Agriculture and Technology.

Ostrom, E., \& Ahn, T. K. (2009). The Meaning of Social Capital and Its Link to Collective Action. In G. T. Svendsen, \& G. Svendsen (Eds.), Handbook of Social Capital: The Troika of Sociology, Political Science and Economics (pp. 17-35). Northampton: Edward Elgar.

Patton, M. (2015). Qualitative Research and Evaluation Methods (4th. ed.). Los Angeles, CA: SAGE.

Putnam, R., Leonardi, R., \& Nanetti, R. (1993). Making Democracy Work. Princeton, NJ: Princeton University Press. https://doi.org/10.1515/9781400820740

Reed, P., \& Selbee, K. (2001). Patterns of Volunteering over the Life Cycle.

Reed, P., \& Selbee, L. K. (2002). Volunteers Are Not All the Same: Heterogeneity in the Voluntary Sector. Statistics Canada.

Rochester, C. et al. (2016). Volunteering and Society in the 21st Century. Berlin: Springer.

Ronoh, G., Mulongo, S., \& Kurgat, A. (2018). Challenges of Integrating Public Participa- 
tion in the Devolved System of Governance for Sustainable Development in Kenya. International Journal of Economics, Commerce and Management, 6, 476-491.

Salacuse, J. W. (2005). Leading Leaders: How to Manage Smart, Talented, Rich, and Powerful People. New York: AMACOM.

Siakilo, E. (2014). Characteristics and the State of Land Ownership in Informal Settlements in Nairobi, Kenya. International Journal of Innovation of Science and Research, 3, 218-226.

Soomro, K. A., Shukui, T., Butt, M., \& Anand, V. (2016). Participatory Governance through Youth Volunteerism in Public Sector of Pakistan. Journal of Public Administration and Governance, 6, 169-180. https://doi.org/10.5296/jpag.v6i2.9722

Suebvises, P. (2018). Social Capital, Citizen Participation in Public Administration, and Public Sector Performance in Thailand. World Development, 109, 236-248. https://doi.org/10.1016/j.worlddev.2018.05.007

Taaliu, S. T. (2017). Corruption in Schools and Universities in Kenya. Open Journal of Social Sciences, 5, 227-231. https://doi.org/10.4236/jss.2017.54020

The Republic of Kenya (2016). County Public Participation Guidelines. Nairobi: Ministry of Devolution and Planning and Council of Governors.

The Republic of Kenya (2018). Nyamira County Integrated Development Plan 2018-2023. Nyamira: County Government of Nyamira.

Thomas, T., \& Mefalopulos, P. (2009). Participatory Communication: A Practical Guide. Washington DC: The World Bank. https://doi.org/10.1596/978-0-8213-8008-6

Thompson, M. (2018). Social Capital, Innovation and Economic Growth. Journal of Behavioral and Experimental Economics, 73, 46-52.

https://doi.org/10.1016/j.socec.2018.01.005

Transparency International Kenya (2019). Corruption Perceptions Index 2018. Transparency International Kenya.

https://tikenya.org/corruption-perception-index-2018-press-release

Uraia (2008). What Is Public Participation? Intellitics.

http://www.intellitics.com/blog/2008/03/24/what-is-public-participation

Welman, C., Kruger, F., \& Mitchell, B. (2005). Research Methodology. Cape Town: Oxford University Press.

Wu, Z., Zhao, R., Zhang, X., \& Liu, F. (2018). The Impact of Social Capital on Volunteering and Giving: Evidence from Urban China. Nonprofit and Voluntary Sector Quarterly, 47, 1201-1222. https://doi.org/10.1177/0899764018784761

Wymer Jr., W. W. (1998). Youth Development Volunteers: Their Motives, How They Differ from Other Volunteers and Correlates of Involvement Intensity. International Journal of Nonprofit and Voluntary Sector Marketing, 3, 321-336. https://doi.org/10.1002/nvsm.6090030406

Yao, K. (2015). Who Gives? The Determinants of Charitable Giving, Volunteering, and Their Relationship.

Yeo, A., Legard, R., Keegan, J., Ward, K., Nicholls, C. M., \& Lewis, C. (2013). In-Depth Interviews. In J. Ritchie, J. Lewis, C. M. Nicholls, \& R. Ormston (Eds.), Qualitative Research Practice: A Guide for Social Science Students and Researchers (pp. 177-208). London: SAGE.

Yilmaz, K. (2013). Comparison of Quantitative and Qualitative Research Traditions: Epistemological, Theoretical, and Methodological Differences. European Journal of Education, 48, 311-325. https://doi.org/10.1111/ejed.12014 